\title{
円筒型十字流式電気限外沪過器の設計方法 ゼラチンコロイド溶液の場合について—†
}

\author{
油川博 · 小林一正
}

\author{
群馬大学工学部 化学工学科 ${ }^{\dagger}$
}

岩田 実

\section{長岡工業高等専門学校 工業化学科 ${ }^{\dagger \dagger}$}

\begin{abstract}
たんぱく質のようなコロイド溶液を限外沪過法で分離濃縮する場合，沪過膜面上に濃縮 したコロイド粒子はゲル状となり，きわめて大きな沪過抵抗を示す．

十字流式電気限外沪過はこの欠点を取り除くために開発されたものである．この沪過方 法は, 電気泳動および膜面近傍に生ずる剪断応力によって, 沪過膜面上に生成するゲル層 の厚さを減少させるので, 沪過流束を増大させるのにきわめて有効である.さらら，ゲル 層および沪過膜の見かけ沪過抵抗は電気浸透により減少する。

本研究は, 前報で示した円筒型十字流式電気限外沪過器の理論的設計式および沪液流束 の実験式に基づき，本実験により検証した設計式を用いて，ゼラチン溶液についての設計 方法を具体的に示したものである.
\end{abstract}

\section{緒言}

最近, 各種化学工業, 食品工業, 製薬工業, 発酵工業 等の諸工業に掞いて, コロイド状分散系の分離濃縮操作 法として限外沪過が多く用いられている。しかしながら， たんぱくやでんぷんのような高分子物質のコロイド溶液 の場合には，限外汇過膜面上に堆積し濃縮された粒子層 はゲル状となり，その沪過比抵抗は通常のケーキ汇過の 比抵抗に比べて执よそ $10^{3} \sim 10^{4}$ 倍も大きいことが知られ ている.

十字流式限外沪過法は, この欠点を補うために, 汇過 原液を限外汇過器内で高速流動させ, 汇過膜面近傍に生 ずる高剪断力によってゲル層の生成をできる限り阻止す るように考案されたものである. 円筒型の十字流式限外 沪過器とゼラチンコロイド溶液を用いて, 沪過流束に及 ぼすレイノルズ数 $(\mathrm{Re})$ の影響について検討した著者ら ${ }^{4)}$ の研究結果によれば, 沪過流束は層流範囲においては $\mathrm{Re}^{0.23}$ に比例し, 乱流範囲では $\mathrm{Re}^{0.7}$ に比例して増加する.

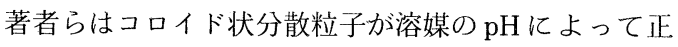
または負の界面動電位いわゆるら電位を有するととに着

†1988年 3 月 30 日受理 ; 化学工学協会第17回秋季大会 (仙台, 1983年 9 月）にて発表

†† $\mathbf{T} 376$ 桐生市天神町 $1-5-1$

††† テ 940 長岡市西片貝町 888
目して直流電場を印加した十字流式電気限外汇過装置を 開発し，その性能と特性について検討した ${ }^{4,5)}$. その結果, 污過流束は電場に比例して増大し，単なる十字流式限外 沪過に比べておよそ数倍増加するてとを示した。

本研究は, 前報 ${ }^{4)}$ で示した円筒型十字流式電気限外沪 過器に関する理論的設計式および沪液流束に関する実験 式に基づいて本実験により検証した設計式を用いて，ゼ ラチンコロイド溶液を使用した場合の汇液流束, 汇過面 積などを求める設計方法を具体的に提示したものである.

\section{1. 十字流式電気限外沪過器の設計方程式}

円筒型の十字流式電気限外沪過器 (十字流式 E. U.F. と略記する）の設計方程式を求めるに際し，次のような 条件を設定する.

1）円筒型十字流式 E.U.F.内の主流は軸方向の流れ であるが，その流速は沪過膜面から流出する汇液によっ て徐じょに減少する。

2）汇過膜面上に堆積する粒子層は，汇過開始初期で は沪過器入口付近で多く，下流方向に徐じょに少なくな るが，沪過時間の経過とともに次第に均一化し，管軸方 向のどの位置に扔いても汇過流束は等しくなる。また， ある沪過時間経過後は, 沪過膜面近傍に生ずる濃度分極 層における濃度勾配による拡散速度と電気泳動速度との 和が沪液流束と等しくなり，ゲル層の生長は停止するの 
で沪過流束一定の定常状態になる。

このような条件に基づき，Fig. 1 亿概略を示した円筒 型の十字流式 E.U.F.について管入口から $l$ の位置に $\mathrm{d} l$ なる微小区間を考え, 分散粒子体積を無視して分散媒に ついての物質収支をとり整理すれば,

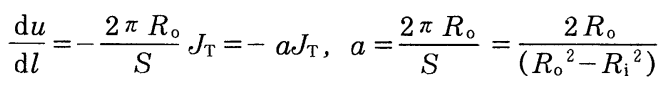

を得る ${ }^{4)}$. ここに, $u$ は $l$ る位置での管断面平均流速, $J_{\mathrm{T}}$ は沪液流束, $R_{0}$ および $S$ はそれぞれ管の半径, 管断 面積である. 定常状態では $l$ 関係なく $J_{\mathrm{T}}$ は一定である から，Eq. (1)を積分して次式を得る.

$$
u=u_{\mathrm{i}}-a J_{\mathrm{T}} l
$$

ここに $u_{\mathrm{i}}$ は管入口に拈ける主流の管断面平均流速であ る.

次に，分散粒子について $\mathrm{d} l$ 部分での物質収支をとり 整理すれば,

$$
\frac{\mathrm{d} C_{\mathrm{b}}}{\mathrm{d} l}=\frac{a J_{\mathrm{T}}}{u}\left(C_{\mathrm{b}}-C_{\mathrm{p}}\right)
$$

Eq. (3) に Eq. (2) を代入して管全体について積分し次の ような設計方程式を得る ${ }^{4 !}$.

$$
\ln \frac{C_{\mathrm{bo}}-C_{\mathrm{p}}}{C_{\mathrm{bi}}-C_{\mathrm{p}}}=\ln \frac{u_{\mathrm{i}}}{u_{\mathrm{i}}-a J_{\mathrm{T}} L_{\mathrm{F}}}
$$

ここに， $C_{\mathrm{bi}}$ 抢よび $C_{\mathrm{bo}}$ はそれぞれ分散粒子の管入口， 管出口に拈ける平均濃度， $L_{\mathrm{F}}$ は管の全長である。屯し， 污過膜の粒子阻止率が $100 \%$ であれば $C_{\mathrm{p}}=0$ となるから， Eq. (4) は次式のように表される.

$$
\ln \frac{C_{\mathrm{bo}}}{C_{\mathrm{bi}}}=\ln \frac{u_{\mathrm{i}}}{u_{\mathrm{i}}-a J_{\mathrm{T}} L_{\mathrm{F}}}
$$

操作条件における $J_{\mathrm{T}}$ が推定できれば，Eq. (4)またはEq. (5) を用いて $a, L_{\mathrm{F}}$ のうち一方を定めれば他方を求める ことができ, したがって所要の沪過面積を決定するとと が可能である.

\section{2. 定常状態における $\boldsymbol{J}_{\mathrm{T}}$ の推算式}

濃度分極層における分散粒子の拡散速度を無視できな いようなコロイド溶液について電気限外沪過を行った場 合には, 次のような沪過特性を示す ${ }^{6,7)}$. 1）汇過過程に おいて膜面近傍に生成する濃度分極層内の濃度勾配によ る拡散速度と電場の印加による電気泳動速度の和が沪液 流束と等しくなる時点でゲル層の生長は停止し, それ以 後沪液流束一定の状態すなわち定常状態となる. 定常状 態に拈けるゲル層の厚さは電気泳動効果により小さくな る.2）ゲル層内に生ずる電気浸透効果および沪液の流 れと反対方向の電気泳動により汇液流束は増加する．3） 汇液流束はある沪過圧力 (これを臨界沪過圧力という)

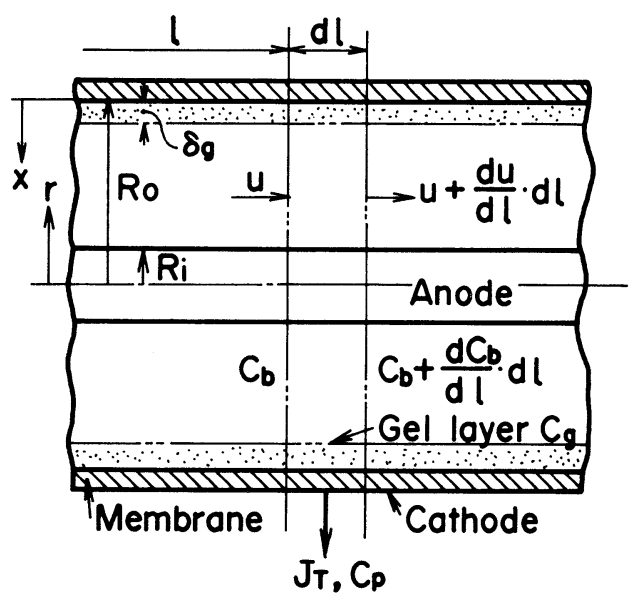

Fig. 1 Schematic mass balance at local position of cross-flow E.U.F.

以上では一定となる.

上述の特性を考慮して, 定常状態における濃度分極層 内の微小体積について分散粒子の物質収支をとれば次式 のような基礎方程式を得る ${ }^{4,6)}$.

$$
J_{\mathrm{T}} C=\left(J_{\mathrm{T}}-u_{\mathrm{E}}\right) C_{\mathrm{p}}+u_{\mathrm{E}} C-D \frac{\mathrm{d} C}{\mathrm{~d} x}
$$

ここにCは膜面から $x$ の位置に打りる分極層濃度, $C_{\mathrm{p}}$ は 沪液中の濃度, $u_{\mathrm{E}}$ は電気泳動速度, $D$ は拡散係数で, 左辺は分散粒子の流入項, 右辺は流出項である. Eq. (6) を書き換えて, $x=\delta_{\mathrm{g}}$ で $C=C_{\mathrm{g}}, x=\delta_{\mathrm{g}}+\delta_{\mathrm{c}}$ で $C=C_{\mathrm{b}}$ の 境界条件で積分すれば

$$
\begin{aligned}
& -\int_{C_{\mathrm{g}}}^{C_{\mathrm{b}}} \frac{\mathrm{d} C}{\left(C-C_{\mathrm{p}}\right)}=\frac{1}{D}\left(J_{\mathrm{T}}-u_{\mathrm{E}}\right) \int_{\delta \mathrm{g}}^{\delta \mathrm{g}^{+} \delta \mathrm{c}} \mathrm{d} x \\
& J_{\mathrm{T}}=\frac{D}{\delta_{\mathrm{c}}} \ln \frac{C_{\mathrm{g}}-C_{\mathrm{p}}}{C_{\mathrm{b}}-C_{\mathrm{p}}}+u_{\mathrm{E}} \\
& =J_{\mathrm{H}}+J_{\mathrm{E}}
\end{aligned}
$$

Eq. (8) の右辺第一項は沪過液圧 $\Delta P_{\mathrm{H}}$ に基づく沪液流束 $J_{\mathrm{H}}$ を表し, 濃度分極層の物質移動係数 $D / \delta_{\mathrm{c}}=K$ とおけ ば

$$
J_{\mathrm{H}}=K \ln \frac{C_{\mathrm{g}}-C_{\mathrm{p}}}{C_{\mathrm{b}}-C_{\mathrm{p}}}
$$

また Eq. (8)の $u_{\mathrm{E}}$ は電場の印加による沪過流束 $J_{\mathrm{E}}$ を表し 電場強度 $E$ に比例するから, 比例定数を $k$ とすれば次式 のように表される.

$$
J_{\mathrm{E}}=k E
$$

先に著者らは, Eq. (9)に打けるKはLinton と Sher $\operatorname{wood}^{2)}$ が提出した円管内壁からの物質移動係数の実験 式と類似であるとみなして

$$
K=\alpha R e^{\beta} S c^{r}
$$

のように表し, ゼラチン溶液を用いた十字流式限外沪過 
実験を行い， $J_{\mathrm{H}}$ に関して層流と乱流範囲によって異なる 次のような士 $15 \%$ の誤差範囲の実験式を得た ${ }^{4)}$.

$$
\left.\begin{array}{c}
J_{\mathrm{H}}=8.96 \times 10^{-11} R e^{0.70} S c^{0.33} \ln \frac{C_{\mathrm{g}}-C_{\mathrm{p}}}{C_{\mathrm{b}}-C_{\mathrm{p}}} \\
3000<R e<5 \times 10^{4} \\
J_{\mathrm{H}}=3.36 \times 10^{-9} R e^{0.23} S c^{0.33} \ln \frac{C_{\mathrm{g}}-C_{\mathrm{p}}}{C_{\mathrm{b}}-C_{\mathrm{p}}} \\
500<R e<2200
\end{array}\right\}
$$

Eq. (10)における $k$ は， $C_{\mathrm{b}}$ が小さく粒子間の相互作用 が無視できる場合には電気泳動度に等しいが，一般的に は粒子の $\zeta$ 電位, 分散媒の誘電率および粘度のほかに $C_{\mathrm{b}}$ の関数である. また， $k$ は流れの影響を受けるから $R e$ の関数である. 先に著者らがゼラチン溶液を用いて行っ た十字流式電気限外汇過実験によれば, Eq. (10) は次の ような士 $20 \%$ の誤差範囲の実験式で示される ${ }^{4)}$.

$$
\left.\begin{array}{rl}
J_{\mathrm{E}}= & k E=2.35 \times 10^{-9} \exp \left(0.31 / \mathrm{C}^{*}\right) R e^{n} E^{\prime} \\
n=-7.87 \times 10^{-3} \mathrm{C}^{*-1.35} \\
3000<\operatorname{Re}<5 \times 10^{4} \\
J_{\mathrm{E}}=k E=\left(3.70 \times 10^{-8}-1.77 \times 10^{-7} \mathrm{C}^{*}\right) \\
\times R e^{-0.05} E \\
500<\operatorname{Re}<2200
\end{array}\right\}
$$

ここに, $C^{*}$ は $C^{*}=C_{\mathrm{bi}} / C_{\mathrm{g}}$ で定義した無次元濃度である. $k$ の值は粒子濃度のほかに $\zeta$ 電位, 分散媒の誘電率上粘 度, 粒子の形状係数等の物性值により異なるが, それら の物性值から $k$ の值を推算することはきわめて困難なの で，取り扱うコロイド溶液について実測する必要があり， ゼラチンコロイド溶液の場合には Eq. (13) のような結果 を得た。

十字流式 E.U.F. の総汇液流束 $J_{\mathrm{T}}$ は, Eq. (8)に示され るように乱流域および層流域それぞれの $J_{\mathrm{H}}$ と $J_{\mathrm{E}}$ の和と して求められる. Eqs. (12), (13)を用いて推算した $J_{\mathrm{T}(\mathrm{cal})}$ と実測值 $J_{\mathrm{T}(\exp )}$ は， $\pm 20 \%$ の䛊差範囲で一致した ${ }^{4)}$.

\section{3. 実験装置および方法}

設計方程式 Eq. (4)の適用性を検証するための実験装置 および方法は, 前報 ${ }^{4)}$ と同じなのでその要点のみを述べ る.十字流式E.U.F.に用いた沪過膜はポリスルホン膜で, 分画分子量は 15000 , 溶質の阻止率は分子量 20000 の場 合执よそ $90 \%$ てある.内径 $2.4 \mathrm{~cm}$, 長さ $100 \mathrm{~cm}$ の円筒型 限外汇過膜の中心部分に直径 $0.7 \mathrm{~cm}$ のステンレス製陽極 と膜の外側に 16 メシュのステンレス製網状陰極を取り 付け, 十字流式E.U.F. 装置の主要部分を構成している. 沪過原液として濃度 $5 \sim 20 \mathrm{~kg} / \mathrm{m}^{3}$ のゼラチン水溶液を用 い，操作中ゲル化するのを防止するため， $38^{\circ} \mathrm{C}$ 一定温 度を保った．ゼラチンの分子量は抢よそ 11 万で, 等電点 は 4.7 である。したがって, $\mathrm{pH} 4.7$ 以上では負の $\zeta$ 電位
を有する.ゼラチン濃度の分析は紫外吸光度法により， $280 \mathrm{~nm}$ の波長で行った。 Re 数抢よびSc 数を求めるのに 必要なゼラチン水溶液の粘度はオストワルド粘度計を用 いて測定した。ゼラチン水溶液の拡散係数は, Flory の 推算式 ${ }^{3)}$ を用いて推算した (Appendix 1). Eq. (13)のE は，正極之負極の電極面積が大きく異なるので, Appendix 2 に示した方法により算出した実効平均電場強度を用い た.

\section{4. 設計式の実験的検証}

十字流式電気限外汇過器の設計方程式の適応性を実験 的に検証するために行った結果をFigs. 2,3に示した. こ れらの図は，それぞれEq. (4) に抽左辺の $\left(C_{\mathrm{bo}}-C_{\mathrm{p}}\right)$ の実測值を縦軸に, Eq. (12) と Eq. (13)を用いて算出し た $J_{\mathrm{T}}$ 值を Eq. (4) に代入して求めた値を横軸にとって比 較したあのである. Fig. 2 は層流域, Fig. 3 は乱流域に おいて $E=0$ の場合と $E \neq 0$ の場合の両方の結果を示す. Figs. 2, 3 ともに土 $5 \%$ の範囲で計算値と実測值は一致し た.

Fig. 4 は, Eq. (4)における左辺の逆数と電場強度 $E$ と の関係について, Eq. (4)による計算値と実測値を比較し て示したものであるが両者は土 $1 \%$ の範囲で一致する. Eq. (4)によれば, $\left(C_{\mathrm{bi}}-C_{\mathrm{p}}\right) /\left(C_{\mathrm{bo}}-C_{\mathrm{p}}\right)$ と $E$ は直線関 係にあるが，実験結果もこのことを示している。また， Fig. 4 は沪過器出口に抢ける濃度 $C_{\mathrm{bo}}$ は $E$ の増大ととも に増加し， $E=0$ の場合に比べて濃縮度が大きくなること を示している。

Figs. 2, 3,4亿示した実験結果加ら, Eq. (4) の妥当性 が確かめられた。

\section{5. 円筒型十字流式 E.U.F.の設計方法}

いま, 汇過原液の処理流量 $Q\left[\mathrm{~m}^{3} / \mathrm{h}\right]$, 濃度 $C_{\mathrm{bi}}$, 汇過 膜の阻止率 $R=1-\left(C_{\mathrm{p}} / C_{\mathrm{b}}\right)$ 抢よび電場強度 $E$ が操作条件 として与えられるとき, 所要沪過膜面積は次のようにし て求めることができる.

\section{5 - $1 u_{1}$ の選定}

Eq. (4)に抢ける $u_{\mathrm{i}}$ は $u_{\mathrm{i}}=Q /\left(\pi R_{\mathrm{o}}{ }^{2}-\pi R_{\mathrm{i}}{ }^{2}\right)$ で表さ れる.Qに比べて沪液流量が小さいてとを考慮して沪過 器内の軸方向流速変化を無視すれば, 沪過器内主流の $R e$ 数は, 相当直径を $2\left(R_{\mathrm{o}}-R_{\mathrm{i}}\right)$ として

$$
R e=\frac{2\left(R_{\mathrm{o}}-R_{\mathrm{i}}\right) u_{\mathrm{i}} \rho}{\mu}=\frac{2 Q \rho}{\pi \mu\left(R_{\mathrm{o}}+R_{\mathrm{i}}\right)}
$$

で表される. Re 数に含まれるコロイド溶液の粘度 $\mu$ は濃 度 $C_{\mathrm{b}}$ の関数であるから実測する必要があるが，本実験 に用いたゼラチン水溶液をオストワルド粘度計で測定し た結果，士 $3 \%$ 誤差範囲で次のような実験式で示され 


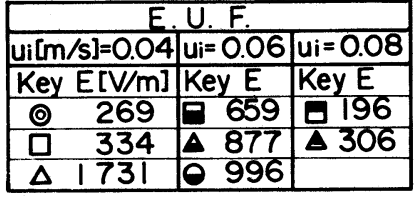

$\left(C_{\text {Do }}-C_{p}\right)_{\text {col,E.U.F. }}\left[\mathrm{kg} / \mathrm{m}^{3}\right]$

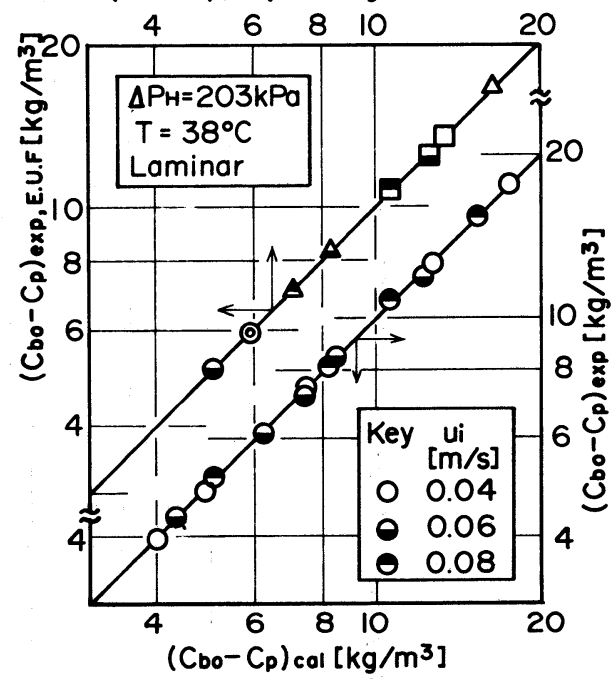

Fig. 2 Comparison of experimental value with calculated value of $\left(C_{\mathrm{bo}}-C_{\mathrm{p}}\right)$ in laminar flow

る。

$\mu=\mu_{0} \exp \left(0.016 C_{\mathrm{b}}{ }^{1.23}\right), 0.2 \leqq C_{\mathrm{b}} \leqq 5 \mathrm{~kg} / \mathrm{m}^{3}$

Eqs. (12),(13) から分かるように $J_{\mathrm{H}}, J_{\mathrm{E}}$ ともにRe 数 の関数であるが，沪過流束に及ぼす $R e$ 数の影響は $J_{\mathrm{H}}$ の 方が $J_{\mathrm{E}}$ に比べて大きく，また乱流域 $(R e>2000)$ での $J_{\mathrm{H}}$ は $R e^{0.7}$ 亿比例して増大するから, 乱流域での適当なRe数 を選択することが望ましい，乙のととを考慮して選択し た $R e$ 数と $\mu$ ， $\rho$ を用いて Eq. (14) から $\left(R_{0}+R_{\mathrm{i}}\right)$ を求め, 電極の太さ $R_{\mathrm{i}}$ を適当に決めたのち $R_{0}$ と $u_{\mathrm{i}}$ を算出する. またての $\left(R_{\mathrm{o}}+R_{\mathrm{i}}\right)$ の值から Eq. (4) の $a$ を求める.

\section{$5 \cdot 2 C_{\mathrm{p}}$ の求め方}

使用する限外汇過膜が決まれば，膜の阻止率 $R=1-$ $\left(C_{\mathrm{p}} / C_{\mathrm{b}}\right)$ から $C_{\mathrm{b}}$ に対する $C_{\mathrm{p}}$ を推定できる．しかし膜の 仕様に示された阻止率から求められる $C_{\mathrm{p}}$ の值は, 分散粒 子の種類, 濃度, $R e$ 数, 電場強度, 温度などにより実 際と異なる場合 ${ }^{5)}$ が多いので，予備実験により実測する 方が確実である．実際の汇過では $C_{\mathrm{p}}=0$ であることが望 ましいが，その場合には小さい分画分子量の膜を選定す る必要があり，したがって沪過流束は小さくなることに 留意する必要がある.

\section{$5 \cdot 3 S c$ 数の求め方}

物質移動係数 $K$ に含まれる $S c$ 数 $(=\nu / D)$ は次のように
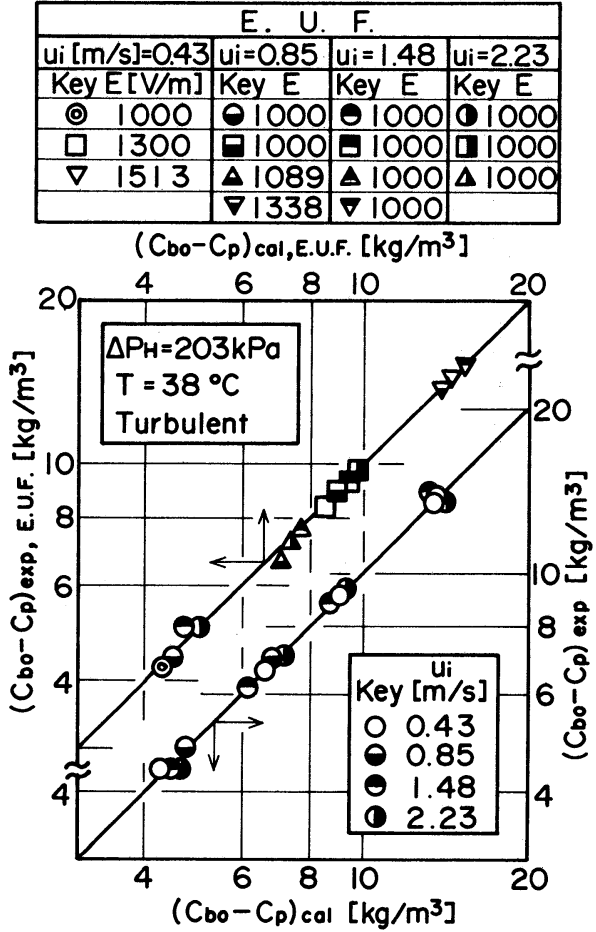

Fig. 3 Comparison of experimental value with calculated value of $\left(C_{\mathrm{bo}}-C_{\mathrm{p}}\right)$ in turbulent flow

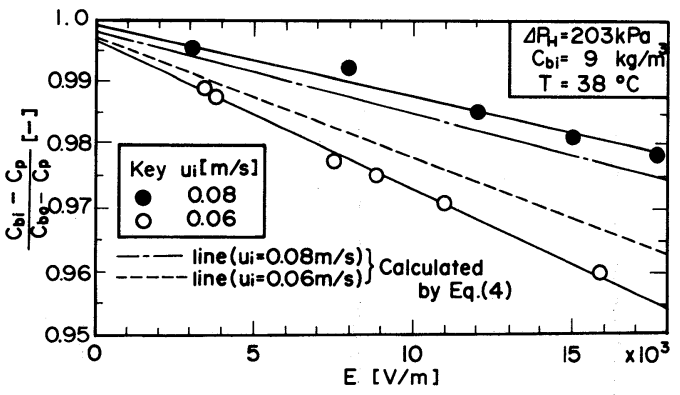

Fig. 4 Relation between $\left(C_{\mathrm{bi}}-C_{\mathrm{p}}\right) /\left(C_{\mathrm{bo}}-C_{\mathrm{p}}\right)$ and $E$

して求められる．コロイド溶液の濃度 $C_{\mathrm{b}}$ に対応する粘 度 $\mu$ と密度 $\rho$ は，それぞれ Eq. (15) 扎よびコロイド粒子 の真比重から算出し, 動粘度 $\nu$ を求める. 次にコロイド 粒子の拡散係数を求めるには, 一般に, 使用したコロイ ド粒子に適用できる推算式を用いればよいが，本研究に 用いたゼラチン水溶液のDについてFloryの式 ${ }^{3)}$ (Appendix 1 ) により推算した值は, $38^{\circ} \mathrm{C}$ の操作温度において $D=$ $4.2 \times 10^{-7} \mathrm{~cm}^{2} / \mathrm{s}$ である.

\section{$5 \cdot 4 \boldsymbol{J}_{\mathrm{T}}$ の推算法}

前述した方法により選定した $R e$ 数と推算した $S c$ 数お よび操作条件である電場強度 $E[\mathrm{~V} / \mathrm{m}]$ を用いて， $\mathrm{Eqs}$. (12), (13) から $J_{\mathrm{T}}$ 値を推算する. 
Eq. (12) における $C_{\mathrm{b}}$ の值は污過器内で $C_{\mathrm{bi}}$ から $C_{\mathrm{bo}}$ ま で連続的に変化する。 したがって, $C_{\mathrm{b}}=C_{\mathrm{bi}}$ として求め た $J_{\mathrm{T}}$ を用いるよりは $C_{\mathrm{b}}=C_{\mathrm{b}}$ として求めた $J_{\mathrm{T}}$ を用いる方 が, Eq. (4)から所要沪過面積を算出した場合やや大きな 値となり, 安全側の設計值となる。乙の場合に必要な $C_{\mathrm{bo}}$ の值は次の手順で求める. 1) $C_{\mathrm{b}}=C_{\mathrm{bi}}$ としてEq.(12) より $J_{\mathrm{H}}$ を求める。. 2) この $J_{\mathrm{H}}$ を用いて $J_{\mathrm{T}}$ を求め, Eq.(4) における $a, L_{\mathrm{F}}$ を設計目標値として仮に定め, 次にてれ らの値を用いて Eq. (4) から $C_{\mathrm{bo}}$ を求める. 3) この $C_{\mathrm{bo}}$ 值 と Eq. (12) とを用いて改めて算出した $J_{\mathrm{T}}$ を設計値とする.

Eqs. (12), (13)の両式に含まれる $C_{\mathrm{g}}, C^{*}$ は次のよう にして求める. Eq. (9) によれば $J_{\mathrm{H}}$ と $\ln \left(C_{\mathrm{b}}-C_{\mathrm{p}}\right)$ の関係 を半対数紙上にプロットすれば勾配がーKの直線となる. この直線を外挿して $J_{\mathrm{H}}=0$ のときの $\left(C_{\mathrm{b}}-C_{\mathrm{p}}\right)$ の値は $\left(C_{\mathrm{g}}\right.$ $\left.-C_{\mathrm{p}}\right)$ を表す。したがって $C_{\mathrm{g}}$ および $C^{*}=C_{\mathrm{b}} / C_{\mathrm{g}}$ が得られ る.ただし， $C_{\mathrm{b}}$ の值は $C_{\mathrm{bi}}$ と $C_{\mathrm{bo}}$ の算術平均を用いた。 $C_{\mathrm{g}}$ は操作温度によって異なるがゼラチン水溶液の $38^{\circ} \mathrm{C}$ における $\mathrm{C}_{\mathrm{g}}$ の実測值は $110 \mathrm{~kg} / \mathrm{m}^{3}$ であった。

\section{5 . 5 所要沪過面積の算出法}

与えられた操作条件から推算した $J_{\mathrm{T}}$ と $5 \cdot 1$ で述べた 方法により決定した $u_{\mathrm{i}}$ を用いれば, Eq. (4)の左辺の値 に対応する沪過器の長さ $L_{\mathrm{F}}$ が求められる. したがって, 汇過面積は $2 \pi R_{\mathrm{o}} L_{\mathrm{F}}$ となる.

もし，汇過膜の形状因子 $L_{\mathrm{F}}, a$ が既知のものを用いた 場合には, Eq. (4) の左辺, すなわち濃縮度を推算できる.

\section{5 - 6 沪過圧力の選定について}

たんぱくコロイド溶液のように, 沪過膜面上に堆積し た粒子層がゲル化する場合の汇過流束は，臨界汇過圧 $\Delta P_{\mathrm{H}(\mathrm{cr})}$ 以上では一定となる7). したがって, 最小の動力 で最大の $J_{\mathrm{H}}$ を得るには $\Delta P_{\mathrm{H}(\mathrm{cr})}$ で操作するのが最む能率 的である. 著者らの研究 ${ }^{7)}$ によれば, $\Delta P_{\mathrm{H}(\mathrm{cr})}$ は $\mathrm{C}_{\mathrm{b}}$ の関 数であり,

$$
\Delta P_{\mathrm{H}(\mathrm{cr})}=A C_{\mathrm{b}}^{-B}[\mathrm{kPa}]
$$

のような実験式で表される. ここに $C_{\mathrm{b}}$ の単位は $\mathrm{kg} / \mathrm{m}^{3}$, また $A, B$ はコイド溶液により異なる実験定数でゼラ チン水溶液の場合には $A=3.04 \times 10^{2} \mathrm{kPa}, B=0.23$ であり, $C_{\mathrm{b}}=10 \mathrm{~kg} / \mathrm{m}^{3}$ の場合 $\Delta P_{\mathrm{H}(\mathrm{cr})}$ はおよそ $203 \mathrm{kPa}$ である.

\section{$5 \cdot 7$ 沪過流束に及ぼす $\mathbf{p H}$ の影響について}

たんぱく質のような両性物質は固有の等電点 $(\mathrm{p} \mathrm{I})$ を 有し, コロイド溶液の $\mathrm{pH} に よ り$ 電位の正, 負および 大きさが異なるので沪液流束は $\mathrm{pH}$ により大きく変化す $る^{5,7)}$. 著者らが牛血清アルブミンおよびゼラチンについ て実測した結果 ${ }^{4,6)}$ によれば，等電点に扔いて $J_{\mathrm{H}}, J_{\mathrm{E}}$ は とあに最小で, $\mathrm{pH} \fallingdotseq 7$ で最大值を示した。このように， 等電点を有するコロイド溶液の沪過に扔いては適切な $\mathrm{pH}$ で操作することが重要である.

\section{$5 \cdot 8$ 消費電力について}

Eq. (13) が示すように, $J_{\mathrm{E}}$ は $E$ に比例する. 消費電力 $P$ と $E$ の関係はOhmの法則より次式で示される.

$$
E=\left(\frac{P}{A_{\mathrm{E}} L \kappa}\right)^{1 / 2}
$$

ここに, $A_{\mathrm{E}}$ は電極面積, $L$ は電極間距離， $\kappa$ はコロイ ド溶液の比電導度である. Eqs. (13), (17)の関係から $J_{\mathrm{E}}$ は $P^{1 / 2}$ に比例するが，乙の関係は実験的にあ確かめられ $た^{4,6)}$. したがって, 電場強度 $E$ に対する消費電力は Eq. (17) から求められる.

\section{結言}

円筒型十字流式電気限外汇過器について理論解析によ り求めた設計方程式 Eq. (4) とゼラチン水溶液について得 られた沪過流束の実験式Eqs. (12),(13) とを用いた, 設 計方法について述べた。

Eqs. (12), (13) における実験定数は沪過原液の種類, 操作温度などによって異なると考えられるので, それに 対応する実験式を求めなければならない欠点はあるが, $J_{\mathrm{H}}$ および $J_{\mathrm{E}}$ を理論的に求めるてとがきわめて困難な状 況での設計方法の一例を提案したあのである.

[ 謝辞 ] 本研究の遂行にあたり協力を得た, 小林健, 首藤健一の両氏に感謝いたします.

\section{Appendix 1}

鎖状高分子が糸まり状をしていると考えられる場合，その高 分子の極限希釈に抢ける拡散係数と分子量の関係を表す式とし て, Flory は次の式を提出している31).

$$
D=\frac{k_{\mathrm{B}} T}{P_{\mathrm{F}} \mu_{0}}\left\{\frac{\Phi}{[\mu] M}\right\}^{1 / 3}
$$

$P_{\mathrm{F}}$ およびゅはFlory の与えた普遍定数で, $P_{\mathrm{F}}=5.11$ であり， また $P_{\mathrm{F}}{ }^{-1} \Phi^{1 / 3}=2.5 \times 10^{6}$ の関係より $\Phi=2.09 \times 10^{21}$ となる.

ゼラチン水溶液の極限粘度数 $[\mu]$ について, Pouradier が イーストマン・コダック社製の皮ゼラチンF 74 に関して次の 関係を求めている ${ }^{1 !}$.

$$
[\mu]=1.66 \times 10^{-5} M^{0.885}
$$

\section{Appendix 2}

Fig.1に扔いて, 任意の半径 $r$ の位置に扔ける電位 $\phi$ は, 電 流密度を $i\left[\mathrm{~A} / \mathrm{m}^{2}\right]$, 溶液の比電導度を $\kappa[1 /(\Omega \cdot \mathrm{m})]$ とすれ ば Ohm の法則より

$$
i=\kappa \frac{\mathrm{d} \phi}{\mathrm{d} r}
$$

全電流 $I[\mathrm{~A}]$ は $\quad I=2 \pi r L_{\mathrm{F}} i$

Eqs. (A 3), (A4)より

$$
\frac{\mathrm{d} \phi}{\mathrm{d} r}=\frac{I}{2 \pi r L_{\mathrm{F}} \kappa}
$$

$r=R_{\mathrm{i}}$ で $\phi=\phi_{\mathrm{Ri}}, r=R_{\mathrm{o}}$ で $\phi=\phi_{\mathrm{Ro}}$ の境界条件で Eq. (A5) を積分すれば，両極間の電位差 $V[\mathrm{Volt}]$ は 


$$
V=\phi_{\mathrm{Ro}}-\phi_{\mathrm{Ri}}=\frac{I}{2 \pi L_{\mathrm{F}} \kappa} \ln \frac{R_{\mathrm{o}}}{R_{\mathrm{i}}}
$$

ゆえに, 実効平均電場強度 $E$ は

$$
E=\frac{V}{\left(R_{\mathrm{o}}-R_{\mathrm{i}}\right)}=\frac{I}{2 \pi\left(R_{\mathrm{o}}-R_{\mathrm{i}}\right) L_{\mathrm{F}} \kappa} \ln \frac{R_{\mathrm{o}}}{R_{\mathrm{i}}}
$$

となり, $I$ と $\kappa$ の実測值から求められる.

\section{Nomenclature}

$$
\begin{aligned}
A_{\mathrm{E}}= & \text { area of electrode } \\
a= & 2 \pi R_{\circ} / S \\
C= & \text { concentration of particles at } x \text { in } \\
& \text { concentration polarization layer } \\
C^{*}= & C_{\mathrm{bi}} / C_{\mathrm{g}} \\
C_{\mathrm{b}}= & \text { bulk concentration of dispersed } \\
& \text { particles }
\end{aligned}
$$$$
C_{\mathrm{bi}}=\text { average concentration of dispersed }
$$
particles at filter tube inlet

$C_{\text {bo }}=$ average concentration of dispersed particles at filter tube outlet

$C_{\mathrm{g}}=$ setting concentration of colloidal solution

$C_{\mathrm{p}}=$ concentration of particles in filtrate $\left[\mathrm{kg} / \mathrm{m}^{3}\right]$

$D$ = diffusion coefficient of dispersed particles

$E \quad=$ effective electric field strength

$I \quad=$ electric current

$i=$ electric current density

$J_{\mathrm{E}}=$ electro-ultrafiltration flux

$\left[\mathrm{A} / \mathrm{m}^{2}\right]$

$J_{\mathrm{H}}=$ ultrafiltration flux

$\left[\mathrm{m}^{3} /\left(\mathrm{m}^{2} \cdot \mathrm{s}\right)\right]$

$\left[\mathrm{m}^{3} /\left(\mathrm{m}^{2} \cdot \mathrm{s}\right)\right]$

$J_{\mathrm{T}}=$ total filtration flux, $J_{\mathrm{T}}=J_{\mathrm{H}}+J_{\mathrm{E}}\left[\mathrm{m}^{3} /\left(\mathrm{m}^{2} \cdot \mathrm{s}\right)\right]$

$K=D / \delta_{\mathrm{c}}=$ mass transfer coefficient of particles in concentration polarization layer $[\mathrm{m} / \mathrm{s}]$

$k=$ proportional constant in Eq. (10) $\left[\mathrm{m}^{2} /(\mathrm{V} \cdot \mathrm{s})\right]$

$k_{\mathrm{B}}=$ Boltzmann constant, $k_{\mathrm{B}}=1.38 \times 10^{-23} \quad[\mathrm{~J} / \mathrm{K}]$

$L=$ distance between electrodes

$L_{\mathrm{F}}=$ length of filter tube

$l=$ distance from filter tube inlet

$M=$ molecular weight

$n=$ experimental constant

$P \quad=$ electric power consumption

$\Delta P_{\mathrm{H}}=$ ultrafiltration pressure

$\Delta P_{\mathrm{H}(\mathrm{cr})}=$ critical ultrafiltration pressure

$Q=$ flow rate of colloidal solution

$\left[\mathrm{m}^{3} / \mathrm{h}\right]$

$R=$ reflection; $R=1-C_{\mathrm{p}} / C_{\mathrm{b}}$
$R e=$ Reynolds number

$R_{\mathrm{i}}=$ radius of inside electrode

[m]

$R_{\mathrm{o}}=$ inside radius of tubular filter

$[\mathrm{m}]$

$r$ = radius

$[\mathrm{m}]$

$S=$ cross sectional area of annulus

$\left[\mathrm{m}^{2}\right]$

$S c=$ Schmidt number

$T$ = absolute temperature

$u$ = average velocity of flow through tubular filter $\quad[\mathrm{m} / \mathrm{s}]$ $u_{\mathrm{E}}=$ electrophoretic velocity of particles $\quad[\mathrm{m} / \mathrm{s}]$ $u_{\mathrm{i}}=$ average velocity of flow at filter tube inlet $[\mathrm{m} / \mathrm{s}]$

$V=$ potential difference between electrodes

$x=$ distance from membrane

$\alpha=$ experimental constant

$\beta=$ experimental constant

$r=$ experimental constant

$\delta_{\mathrm{c}}=$ thickness of concentration polarization layer

$\delta_{\mathrm{g}}=$ thickness of gel layer

$\zeta=$ electrokinetic potential of particle

$\kappa=$ specific conductivity of colloidal solution

$[1 /(\Omega \cdot m)]$

$\mu=$ viscosity of colloidal solution

$[\mathrm{kg} /(\mathrm{m} \cdot \mathrm{s})]$

$[\mu]=$ limiting viscosity number $\left[100 \mathrm{~cm}^{3} / \mathrm{g}\right]$

$\mu_{0}=$ viscosity of dispersion medium $[\mathrm{kg} /(\mathrm{m} \cdot \mathrm{s})]$

$\nu=$ kinematic viscosity of colloidal solution

$\left[\mathrm{m}^{2} / \mathrm{s}\right]$

$\rho=$ density of colloidal solution

$\left[\mathrm{kg} / \mathrm{m}^{3}\right]$

\section{Literature cited}

1) Akabori, S.: “Tanpakushitsu-kagaku”, p.453, Kyoritsu - shuppan (1964)

2) Linton, W.H. and T.K. Sherwood: Chem. Eng. Progr., 46, 258 (1950)

3) Nakajima, A. and M. Hosono: "Koubunshi-noBunshibussei (vol.2 )”, p.339, Kagaku-dojin(1970)

4) Yukawa, H., K. Shimura, A. Suda and A. Maniwa: J. Chem. Eng. Japan, 16, 305 (1983)

5) idem: ibid., 16, 246 (1983)

6) Yukawa,H., H.Obuchi and K. Kobayashi : Kagaku Kogaku Ronbunshu, 6, 288 (1980)

7) idem : ibid., 6, 323 (1980) 


\title{
Design of Cylindrical Cross-Flow Electro-Ultrafilter
}

- For case of gelatin colloidal solution -

\author{
Hiroshi Yukawa and Kazumasa Kobayashi \\ Dept. of Chem. Eng., Gunma Univ., Kiryu 376
}

Minoru Iwata

Dept. of Appl. Chem., Nagaoka Technical College, Nagaoka 940

Key Words : Membrane Separation, Electro-Ultrafiltration, Cross Flow, Gelatin Colloidal Solution, Design Method

When colloidal solutions containing such materials as protein are separated and concentrated by ultrafiltration, colloidal particles thickened on the filtration membrane become gelatinous and exhibit very high filtration resistance.

Cross-flow electro-ultrafiltration has been developed to remove the bottleneck. The filtration flux is increased because the thickness of the gel layer formed on the membrane is decreased by electrophoresis and by the shear force caused near the membrane. Moreover, the filtration resistances of the gel layer and the membrane are apparently decreased by electroosmosis.

In this paper, a design method for cross-flow electro-ultrafiltration is proposed for the case of gelatin colloidal solution based on the design and experimental equations of filtration flux obtained previously and a design equation confirmed experimentally in this study. 